\title{
25 Research Soure \\ Integrated reporting and firms' performance of listed ICT companies in Nigeria
}

\author{
Aminu Abdullahi Kaura \\ Usmanu Danfodiyo University Sokoto \\ Abdulrasheed Bello ( $\square$ abdul2sapna@yahoo.com ) \\ Nigerian Airspace Management Agency \\ Sirajo Sani Sokoto \\ Sokoto Internal Revenue Services Sokoto
}

\section{Research Article}

Keywords: Market value added, Integrated reporting, performance

Posted Date: September 14th, 2021

DOI: https://doi.org/10.21203/rs.3.rs-900392/v1

License: (c) (i) This work is licensed under a Creative Commons Attribution 4.0 International License. Read Full License 


\section{Abstract}

The purpose of this study is to examine the effect of corporate performance of 9 listed ICT companies in Nigeria over a period of ten years $(2011-2020)$. MVA and ROA were employed as market and financial based measures of performance and controlling for Leverage, Firm size and Age. Panel regression was employed using fixed effect model to test the study hypothesis. The findings from the analysis revealed a positive and significant association between IRINDEX and MVA while the result was insignificant between $R O A$ and IRINDEX. All the control variables were significantly associated with IRINDEX. The model was also significant with $\mathrm{f}$-statistics probability significant at $1 \%(0.000)$ level. The model account for about $66.21 \%$ variation in IRINDEX. The study therefore concluded that, corporate performance affect IR only in the longrun. The study recommended that, regulatory agencies in Nigeria should enact laws that make it mandatory for quoted companies to adopt IR or grant tax credit to voluntary compliers and lastly, managers should strive to adopt IR not minding its cost implication in the short-run as the benefit will accrue in the long-run.

\subsection{Introduction}

In 2010 a coalition comprising of regulators, investors, companies, standard setters, accounting professional bodies, academia, and NGOs jointly formed an International Integrated Reporting Council (IIRC) with the belief that communication of value created, preserved, or eroded to all stakeholders is the next step in the evolution of corporate reporting and this can only be achieved through Integrated Reporting (IR) (IIRC, 2021). Therefore, the body developed a framework (International Integrated Reporting Framework) with the sole aim of establishing guiding principles and content elements that govern the overall content of IR and explain the fundamental concepts that underpin the preparation of this report.

Over the last decade, IR has been voluntarily gaining ground as a concept and in practice in developing and developed nations (Frias-Aceituno et al., 2014; Ismal, 2020), IR is a new phenomenon in the field of corporate reporting that shifted from the short-term concentration of value creation for shareholders to a more concise reporting on the long-term creation of value to all stakeholders affected by economic activities of entities which will aid them in making an informed and prudent decisions (Hossain et al., 2016; Ahmed Haji \& Anifowose, 2016). Recent evidence from empirical findings questioned the practice of IR by economic entities whether satisfying the need of all stakeholders has any effect on the companies' performance (Brown \& Dillard, 2014). Meeting stakeholders' need lead to changes in corporate behavior as well as enhances their reputation and performance (Hoque, 2017).

It is in view of this, that academics, students, and policymakers tried to determine the impact of performance on IR (Islam, 2020; Aifuwa, 2020; Buallay et al., 2020) others examine whether IR lead to creation of value (Bijlmakers, 2018; Nurkumalasari et al., 2019; Komar et al., 2020). Of the studies conducted, there is yet to be a consensus as to the effect of IR on performance and or value creation. Of the studies conducted emphasis was mainly on financial measures of performance like ROA, ROE, EPS, etc. (Buallay et al. 2020; Islam, 2020) neglecting the effect of other performance measures, like Market-based, economic-based, survival measures among others. Despite the growing empirical literature on IR, little attention is given in determining the 
impact of IR on performance and value creation in developing countries like Nigeria (Adegbie, et al. 2019; Adegboyegun et al., 2020). Studies conducted in Nigeria tried determining the effect of IR on the performance of Banks and that of manufacturing companies without regard to other sectors of the Nigerian Stock Exchange (NSE). It is in view of this that this study is conducted to determine the effect of performance on IR by employing financial and market-based measures of performance of listed Information and Communication Technology companies (ICT) in Nigeria and introducing control variables.

\subsection{Literature Review}

This section provides a review of the concept of IR, corporate performance, and the theories relevant to the study, and lastly, it reviews existing literature on IR.

\subsection{Integrated reporting}

Integrated reporting as define by IIRC (2013) is the reporting of strategy, governance, performance, and prospects of an organization in a concise and precise manner to various stakeholders in its bid to create value in the long run. IR entails the integration of both financial and non-financial information in a single report, (Islam, 2020). To develop a guiding principle for its implementation, various parties came up together and designed IR Framework. The framework is established as a guide and it prescribed content elements that govern its preparation. The guiding principles stated that IR should have a strategic focus and be futureorientated, connect information and show a holistic view of an organisation, describe organizational relationships with stakeholders, contain material information, be concise, reliable, and complete, and be consistent and be able to be compared with other organizations' reports (IIRC, 2013). IR is designed primarily to communicate those factors that materially affect the ability of organizations to create value, promote more cohesive and efficient corporate reporting (International Integrated Reporting Framework (IIRF), 2021).

The framework set eight elements here refer to as "Content Elements". These elements set the categories of information required to be included in an integrated report; which are fundamentally linked to each other and are not mutually exclusive. They are stated in form of questions to be answered in a way that makes the relationships between them apparent. They include organizational overview and external environment, governance, business model, risk and opportunities, strategy and resource allocation, performance, outlook and lastly basis of preparation and presentation. Seven guiding principles underpin the preparation and presentation of this report aimed at informing the content of report and how the information in it should be presented. IR was built on the principle of value creation in the short, medium, and long-term by promoting integrated thinking and communication to users which will be achieved through the concept of six capitals (IIRC, 2013). The capitals are, financial, manufacturing, intellectual, human, social and relationship, and natural capitals that can be communicated to inform key performance indicators (KPIs).

\subsection{Corporate performance}

To meet stakeholders' expectations managers, strive to improve the performance of their organization. The concept of organizational performance is based upon the idea that an organization is a voluntary association of productive assets, including human, physical, and capital resources, to achieve a shared 
purpose (Isaac, et al., 2016). More recently defined Taouab and Issor (2019) see corporate performance as the degree by which an organization achieves its set goals with its limited resources and within the minimum stipulated time. In the word of Lebans and Euske (2006), performance is seen as the capability and ability of an organization to efficiently and effectively utilize its available resources to achieve the organization's goal at the same time adding value to its capital providers.

\subsection{Theoretical framework}

In discovering whether IR practices depend on the level of performance of companies, studies conducted used various theories in achieving this objective (Agency theory, institutional theories, signaling theory, stakeholder theory, legitimacy theory, shareholder theory, etc.). This section highlights the most relevant theories of integrated reporting. Chatelain and Morrain (2012) highlighted that three major theories are surrounding IR, the Stakeholder theory, shareholder theory, new institutionalism and legitimacy theory, and lastly innovation diffusion theory. IR in relation to value creation revolved around the integration of two theories, the shareholder and stakeholder theories (Eccles et al., 2012). In view of the above, this study is underpinned by adopting the signaling.

Signaling theory is applied to clarify voluntary disclosure in corporate reporting (Ross, 1977), even though it was initially developed to explain the information asymmetry in the labour market (Spence, 1973). Due to the information asymmetry issue, companies signal particular information to attract investments in the market and to enhance a positive reputation (Verrecchia, 1983). Signalling theory is valuable for analyzing disclosure behaviour when two organisations or individuals have different information. Usually, the sender decides whether and how to communicate the information, and the receiver defining the information received. This clarifies why companies are stimulated to disclose voluntarily more information than the mandatory ones required by laws and regulations (Campbell et al., 2001), that is to appear positively in the market (Spence, 1973; Connelly et al., 2011). As expressed in signalling theory, companies have several means to signal information about themselves.

\section{$2.4 \quad$ Empirical review}

There is controversy over the relevance of non-financial disclosures on investment decision-making and corporate performance (Qiu, et al., 2014). While examining the relationship between Tobin's Q used as a proxy for value creation and IRQ, Lee and Yeo (2016) sampled 822 firms listed on the South African Stock Exchange over a period from 2010 to 2013 . Findings from the result revealed that IRQ is positively linked with Tobin's $Q$ and discover that, the association is higher with complex firms and firms with external financing needs. The findings of Leo and Yeo (2016) was contradicted by Albetairi et al. (2018) while assessing the effect of IR on the financial performance of five firms in Bahrain between 2012 and 2015 with the use of POLS regression technique, it was revealed that IR indices have mixed effect on firm performance to the end that risk and opportunities index, as well as a performance index, exert a negative influence on performance. Cosma et al. (2018) examined the effect of the Integrated Report on firm value in South Africa between 2013 and 2016. The regression results revealed that IR has a positive effect on firm performance. As a result, it was proposed that firm managers should step up in their IR disclosure quality. 
Soumillion (2018) examined the value relevance of IR of 63 firms in South Africa in 2017. Descriptive statistics and POLS regression were used to analysed the data. It was revealed that IR has no significant impact on firm value. Hence, it was recommended that IR should be strictly adhered to and regulated. Bijlmakers (2018) also explored the influence of IR on firm value in 56 banking firms in Europe between 2010 and 2016. Also, descriptive statistics and the POLS regression were used as technique of data analysis, it was revealed that IR has no significant impact on firm value. This was later supported by Nurkumalasari et al. (2019) that examined the effect of IR disclosure on the value of 14 firms in Asia between 2015 and 2017. Employed for the analysis were descriptive statistics and POLS regression techniques, it was revealed that IR does not affect firm value especially in cases of high leverage. Hence, it was suggested that highly levered firms should reduce their debt in a bid to make IR more relevant. Affan (2019) while examining the impact of voluntary disclosure (IR) on a company's performance. Data on a sample of 58 companies was obtained from Indonesia Stock Exchange (IDX). The result revealed that disclosure of financial and non-financial information in a single report affects the corporate performance of companies listed on IDX. This was affirmed by Vitolla et al. (2019). Vitolla et al. (2019) explore whether intellectual capital disclosure (ICD) affect IR performance, performance was measured using ROE while content analysis was used to quantify ICD. The finding revealed a significant and positive association between intellectual disclosure quality and firm performance.

El Deeb (2019 studied the impact of integrated reporting on firm value and performance, ROE and leverage level were used as proxies for firm performance, and capitalized market value was used as a proxy for firm value. The findings of the research were in support of a positive correlation between the level of IR compliance and firm performance, value, and the leverage level of the companies. More recently, Omran, et al. (2020) investigated the relationship between IR and corporate environmental performance using a sample of 110 firms listed on the Johannesburg Stock Exchange for a period of five (5) years (2014 - 2018). The result from the analysis revealed a positive association between IR and corporate environmental performance which was later supported by Komar et al (2020). During the same period, Islam, (2020) investigated the relationship between integrated reporting and firm performance in a voluntary disclosure regime. The findings revealed that IRDIN is positively and significantly related to all the three performance variables. Aifuwa (2020) faulted the findings of Omran, et al. (2020), Komar et al (2020), and Islam, (2020) while exploring the effect of sustainability reporting on firm performance in developing climate, a systematic content analysis approach was employed to achieve the objective and the review revealed the inconclusive impact of sustainability reporting on firms' performance.

Hongming et al. (2020) examine the influence of sustainability reporting on firm performance, the sustainability reporting index was measured using content analysis procedure extracted from GRI and performance represented by ROA. The results show that social and environmental indicators have a significant positive impact on firm performance, while health and safety indicators show a significant but weak impact on firm performance in Pakistan. Zehir \& Ozgul, (2020) on the issue of Environmental orientation on firm performance designed and administered questionnaires to obtain information for both dependent and independent variables, an empirical proof shows that internal and external environmental orientation has a positive effect on both green product innovation and green process innovation, also internal environmental orientation has a direct positive effect on firm performance, while external 
environmental orientation has an indirect effect. Udofia et al. (2020) investigated the readiness of Nigerian listed companies to adopt Integrated Reporting (IR). Content analysis was used to develop an IR index. Nigerian listed companies' reports comply with about $75 \%$ of the IR framework requirements. The most compliant companies were the financial sector, followed by manufacturing, extractive, and other sectors. The least disclosed IR content element in all the sectors was performance. Adegboyegun et al. (2020) examined the impact of integrated reporting on the performance of corporate organizations in Nigeria between 2009 and 2018. The result from the analysis revealed that while IR has no significant impact on corporate performance in the short run, it has a significant relationship with firm performance in the long run.

\subsection{Methodology}

As of the time of writing this, there are 10 listed ICT companies in Nigeria. Due to the limited number of companies, census sampling was employed. Out of the total population, one company was removed due to non-availability of data during the study period. Data was collected from sampled companies' websites, APT Securities, and Nigeria Exchange Group for a period from 2011 to 2020. IRIndex being the dependent variable was measured with the help of content analysis as in Shirley (2016) and Adegboyegun. et al. (2019) (adapted). Independent variables are Return on Asset (ROA) and Market Value Added (MVA) used as proxies for financial and market-based performance measure respectively. Leverage, age, and Firm Size were employed as control variables. Panel regression is used for analysis with the aid of Eviews 10 and STATA version 14.2 software. Diagnostic tests were carried out to avoid spurious repression results.

\subsection{Model specification}

OLS will lead to heterogeneity bias and produce spurious results where heterogeneity exist, (Greene, 2020). The best approaches to addressing heterogeneity bias are the fixed-effects model and the random-effects model. The general form of the panel data model can be specified more compactly as:

$Y_{i t}=\mathrm{a}_{0}+\mathrm{a}_{1} x_{i t}+\mathrm{a}_{2} x_{i t}+\ldots+\beta_{k i t}+e_{i t}$

1

The modified empirical model following the work of Cheng et al. (2014), Buallay et al. (2020) and Adelowotan and Udofia (2021) with the inclusion of other variables not included in their studies.

IRINDEX $i t=a_{0}+a_{1} M_{i t}+a_{2} R O A_{i t}+a_{3} L E V+a_{4} F_{S I Z E_{i t}}+a_{5} A G E_{i t}+e_{i t} \ldots \ldots \ldots \ldots . . .2$

Where, IRINDEX (Integrated reporting index), MVA measures as = Enterprise value (EV) - Economic book value $(E B V)$ where $E V=$ Market Value of Equity $(M V E)+$ Market Value of Debt (MVD) while EBV = Book Value of Equity (BE) + Book Value of Debt (BVD) as in Rafindadi and Bello (2019). ROA measures as Net profit after taxes/Total Assets. FSize was measures as the Natural log of Total Assets. Age was defined as the No. of years of company from incorporation to 2020.

\subsection{Empirical Results And Analysis}

This section analyses the data collected from the sampled companies and discusses results from the analysis primarily to test research hypothesis. 


\subsection{Descriptive Statistics}

This present the summary of the study variables as in Table 1 below

Table $1 \quad$ Descriptive Statistics result

\begin{tabular}{lllllll} 
& MVA & ROA & IRINDEX & LEV & FSIZE & AGE \\
\hline Mean & 0.490635 & 0.034558 & 10.97444 & 0.734665 & 0.836158 & 23.38889 \\
\hline Median & 0.002146 & 0.021730 & 10.20000 & 0.931075 & 0.828429 & 19.00000 \\
\hline Maximum & 4.483291 & 0.154699 & 17.00000 & 1.986733 & 0.980989 & 71.00000 \\
\hline Minimum & $8.93 \mathrm{E}-07$ & -0.003495 & 5.610000 & -3.084863 & 0.720870 & -7.000000 \\
\hline Std. Dev. & 1.035920 & 0.038882 & 3.188679 & 1.000599 & 0.059166 & 18.91180 \\
\hline Observations & 90 & 90 & 90 & 90 & 90 & 90
\end{tabular}

Table 1 revealed a mean value of N0.490635 against MVA which can be interpreted to mean that, ICT companies have created value to the tune of $\mathrm{N} 490,635,000.00$ on average. Also reported was an average value of N0.034558 against ROA which also implies that every N1 of ICT assets have generated N0.034558 of net profit after tax during the study period on average. Though some companies reported a negative ROA during the period as can be seen from the minimum value against the ROA. IRINDEX has a mean score of 10.97 and the maximum achievable is 17 , we can infer that ICT companies are to a large extent complying with the content element of IR. Leverage, Fsize, and Age all reported a mean value of $0.735,0.8362$, and 23.39 respectively. This implies that the average age of sample companies from incorporation as at the end of the study period is 23.4 years, though some companies were not incorporated as at the beginning of the study period, this is evident by the minimum years of -7 against Age.

\subsection{Correlation analysis}

Table 2 is a correlation matrix and test for multicollinerity between variables

\begin{tabular}{lllllll} 
Variables & ROA & MVA & FSIZE & LEV & AGE & VIF \\
\hline ROA & 1 & & & & \\
\hline MVA & $0.5454^{\star}$ & 1 & & & \\
\hline FSIZE & -0.1677 & -0.1785 & 1 & & 1.90 \\
\hline LEV & -0.0171 & -0.1275 & 0.1601 & 1 & 1.52 \\
\hline AGE & $-0.5125^{\star}$ & $-0.4594^{\star}$ & -0.1153 & $0.4101^{\star}$ & 1 & 1.29
\end{tabular}

Table 2 Correlation matrix and Multicollinearity test

* Significance level at $1 \%$. 
Correlation matrix presented in Table 2 shows a positive relationship between ROA and MVA, Lev and FSIZE, Lev and Age while that of ROA and Age, Lev and Age were all negatively correlated all at $1 \%$ level of significance. Table 2 also reveal the absence of multicollinearity between the study variables as the highest VIF value is 2.19. Multicollinearity problem arises where VIF values is $>10$ (Kutner \& Switala, 2004; Farahani, et al, 2010).

\subsection{Panel unit root test}

Presented in Table 3 revealed that all the variables under consideration are stationary in their levels except for MVA and LEV that became stationery at first difference.

Table 3 Panel unit root test result

\begin{tabular}{|c|c|c|c|c|c|c|c|c|}
\hline \multicolumn{5}{|c|}{ Level } & \multicolumn{4}{|c|}{ First difference } \\
\hline Variables & $\begin{array}{l}\text { Levin, } \\
\text { Lin \& } \\
\text { Chu }\end{array}$ & $\begin{array}{l}\text { Im, } \\
\text { Pesaran } \\
\text { and } \\
\text { Shin }\end{array}$ & ADF & PP & $\begin{array}{l}\text { Levin, } \\
\text { Lin \& } \\
\text { Chu }\end{array}$ & $\begin{array}{l}\text { Im, } \\
\text { Pesaran } \\
\text { and } \\
\text { Shin }\end{array}$ & $A D F$ & PP \\
\hline \multirow[t]{2}{*}{ IRINDEX } & -21.1193 & -7.60461 & 34.1554 & 42.0987 & & & & \\
\hline & $0.0000 *$ & $0.0000 *$ & $0.0021^{\star}$ & $0.0011^{\star}$ & & & & \\
\hline \multirow[t]{2}{*}{ MVA } & & & & & -5.80289 & -1.14612 & 28.3113 & 40.5840 \\
\hline & & & & & $0.0011^{\star}$ & $0.0100 *$ & $0.0029 *$ & $0.0002^{*}$ \\
\hline \multirow[t]{2}{*}{$R O A$} & -4.27463 & -1.92798 & 31.4938 & 41.3937 & & & & \\
\hline & $0.0000 *$ & $0.0069 *$ & $0.0052^{\star}$ & $0.0013^{\star}$ & & & & \\
\hline \multirow[t]{2}{*}{ LEV } & & & & & -8.91300 & -3.81855 & 53.8799 & 84.5058 \\
\hline & & & & & $0.0000 *$ & $0.0001^{\star}$ & $0.0000 *$ & $0.0000 *$ \\
\hline \multirow[t]{2}{*}{ FSIZE } & -6.57670 & -2.56416 & 41.3496 & 55.3118 & & & & \\
\hline & $0.0000 *$ & $0.0052^{\star}$ & $0.0014^{\star}$ & $0.0000 *$ & & & & \\
\hline \multirow[t]{2}{*}{$A G E$} & -13.0733 & -100.053 & 149.005 & 147.365 & & & & \\
\hline & $0.0000 *$ & $0.0000 *$ & $0.0000 *$ & $0.0000 *$ & & & & \\
\hline
\end{tabular}

* Significance level at $1 \%$.

\subsection{Regression modeling}

Normality test conducted revealed that our residuals are normally distributed, this can be seen from the Jarque-Bera statistics result presented in Table 6. To test for heteroscedasticity, Breausch pagan test was carried out which revealed that our data is homoscedastic. Breusch and Pagan Lagrangian multiplier test for random effects was employed to choose between POLS and RE, the result was $<5 \%$ therefore the null 
hypothesis that POLS is the most appropriate was rejected. Hausman test was conducted to choose between FE and RE and the result revealed that the FE model is the most appropriate.

\section{Table $6 \quad$ Regression result}

The table summarizes the equation's results using Pooled OLS, Random effect, and Fixed Effects models:

\begin{tabular}{|c|c|c|c|c|c|c|}
\hline & OLS & & $R E$ & & $F E$ & \\
\hline Variables & Coeff. & $\begin{array}{l}t \text {-test }(p- \\
\text { value })\end{array}$ & Coeff. & $\begin{array}{l}z \text {-test }(p- \\
\text { value) }\end{array}$ & Coeff. & $\begin{array}{l}\text { t-test }(p- \\
\text { value })\end{array}$ \\
\hline$M V A$ & 2.5681 & $\begin{array}{l}9.59 \\
(0.000) *\end{array}$ & 2.0527 & $\begin{array}{l}4.31 \\
(0.000) *\end{array}$ & 2.7019 & $\begin{array}{l}0.36 \\
(0.020) * *\end{array}$ \\
\hline$R O A$ & 3.0422 & $0.39(0.493)$ & -4.8576 & $-0.69(0.493)$ & -2.7005 & $-0.59(0.554)$ \\
\hline LEV & 0.0491 & $0.24(0.985)$ & -0.0041 & $-0.02(0.985)$ & 0.3337 & $\begin{array}{l}2.28 \\
(0.026) * *\end{array}$ \\
\hline FSIZE & 16.6923 & $4.32(0.266)$ & 9.6427 & $1.11(0.266)$ & -3132948 & $-3.09(0.003) *$ \\
\hline$A G E$ & 0.02743 & $\begin{array}{l}2.09 \\
(0.005) *\end{array}$ & 0.0824 & $\begin{array}{l}2.78 \\
(0.005) *\end{array}$ & 0.4794 & $11.76(0.000) *$ \\
\hline C & -4.9739 & $-1.44(0.979)$ & 0.1941 & $0.03(0.979)$ & 25.9332 & $3.17(0.002)$ \\
\hline$R^{2}$ & 0.6492 & & 0.1635 & & 0.6621 & \\
\hline$P$-value & 0.0000 & & 0.0001 & & 0.0000 & \\
\hline
\end{tabular}

$\begin{array}{ll}\text { Jarque-Bera } & 1.780935 \\ \text { (p-value) } & (0.410464)\end{array}$

Heteroscedasticity Chi-square: 0.05 (p-value: 0.8224)

Breausch-pagan Chi-square: 5.79 (p-value: 0.0081)

test

Chi-square: 192.21 (p-value: 0.0000)

Hausman test

Observations

90

90

90

Note: The dependent variable is Integrated reporting index (IRINDEX). Explanatory variables are Market value added (MVA) and Return on asset (ROA). Control variables introduced are, Leverage (LEV), Firm size (FSIZE) and Age (AGE). ${ }^{*}, * \star$, indicates significance level at $1 \%$ and $5 \%$ respectively

The $\mathrm{R}^{2}$ of 0.6621 implies that MVA and ROA alongside control variables (LEV, FSIZE, and Age) introduced account for $66.21 \%$ changes in the dependent variable (IRINDEX) as explained by our model. MVA as a market measure of performance exhibits a positive and significant relationship with IRINDEX with a p-value $0.020<5 \%$ significance level. This implies that ICT companies comply with the content of IRF purposely to signal the expectation of their future growth to the public, this supported the assertion of signalling theory. This outcome is in line with the findings of Lee and Yeo (2016), Martinez (2016), Barth et al. (2017) and El 
Deeb (2019) that IR is positively associated with market value. Surprisingly the result revealed that ROA as an accounting measure of performance has no significant effect on IRINDEX as its p-value is $>1 \%, 5 \%$, and $10 \%$ level of significance, and the coefficient was negative, this is in compliance with the outcome of Mukeredzi (2019), Tlili et al. (2019) and Adelowotan and Udofia (2021). It implies that performance measured by ROA does not affect IR in the short run. The findings contradicted that of Pasquini-Descomps and Sahut (2013), Girella et al. (2019), Vitolla et al., 2019 and Islam (2020) that established a positive and significant relationship between ROA and IR. All the three control variables introduced exhibit a significant relationship with IR and the relationship was positive except for FSIZE that has a negative relationship.

Leverage with a p-value of 0.026 indicates that higher levered companies are more likely to comply with the content of IRF than the less levered firms, this contradicted the findings of Kılıç and Kuzey (2018), and Islam (2020) but supported De Villiers et al. (2016). This is possibly because presenting both financial and nonfinancial information will give the firm more access to credit facilities. Also, Age with a p-value of 0.000 indicates that the older the incorporation of a company the higher the level of their compliance and vice versa holding all other factors constant. FSIZE is also a determining factor upon which companies comply with the content of IRF but presented a negative coefficient, this implies that the bigger the company is the lower the probability of it adopting or complying with the content of IR, this also opposed the findings of Lee and Yeo (2016), Bernardi and Stark (2017), Zhou et al., (2017) and Islam (2020) who stresses that, the larger the firms the higher possibility of reporting in integrated form.

\subsection{Conclusion And Recommendations}

The findings from the analysis revealed that the sampled companies have been reporting some content elements of IRF in their financial report some in a standalone report while others in an integrated form even before the emergence of IR and that the practicing has increased considerably. Also discovered was that, performance has no effect on the adoption of IR in Nigeria in the short run while it was evident that it does in the long run while controlling for other variables like leverage, age and the size of firm. These control variables introduced were all significant factors in determining the adoption of IR in Nigeria. This outcome has policy implication on regulatory authorities in their policy formulation in relation to corporate reporting. The outcome of this study will guide existing and potential investors on the need to reinvest, invest or divest their funds from companies not practicing IR.

In view of the foregoing, the study recommends that, regulatory authorities should impose or enact laws that will make it mandatory for all companies to adopt IR system of reporting or should grant tax credit to companies that voluntarily adopt. Managers should also strive to ensure that their reports comprised of both financial and non-financial information thereby aiding stakeholders in taking relevant decision. Managers should also enlighten their shareholders on the positive impact IR has on their going concern in the long-run by overlooking the cost associated with its implementation or adoption.

\section{Declarations}

Competing interests: The authors declare no competing interests. 


\section{References}

Adegbie, F. F., Akintoye, I. R. \& Bello, I., (2019). Evaluation of Integrated Reporting and the Value of Listed Manufacturing Firms in Nigeria. European Journal of Accounting, Auditing, and Finance Research, 7(7). 93-121.

Adelowotan, M.O. \& Udofia, I.E., 2021, 'Do corporate attributes drive integrated reporting amongst listed companies in Nigeria?', Journal of Economic and Financial Sciences 14(1), 673. https://doi.org/10.4102/jef.v14i1.673

Adegboyegun, A.E., Alade, M.E., Ben-Caleb, E., Ademola, A.O., Eluyela, D.F. \& Oladipo, O.A. (2020). Integrated reporting and corporate performance in Nigeria: evidence from the banking industry, Cogent Business and Management, 7(1).

Affan, M. W. (2019). Integrated Reporting and Corporate Performance: Empirical Evidence of The IIRC Framework Adoption. Jurnal Ilmiah Bidang Akuntansi dan Manajemen, 16(2), 181-186. http://riset.unisma.ac.id/index.php/jema

Ahmed Haji, A., \& Anifowose, M. (2016). The trend of integrated reporting practice in South Africa: ceremonial or substantive? Sustainability Accounting, Management and Policy Journal, 7(2), 190-224. https://doi.org/10.1108/sampj-11-2015-0106

Aifuwa, H. O. (2020). Sustainability Reporting and Firm Performance in Developing Climes: a Review of Literature. Copernican Journal of Finance \& Accounting, 9(1), 9-29.

Albetairi, H. A., Kukreja, G., \& Hamdan, A. (2018). Integrated Reporting and Financial Performance:

Empirical Evidences from Bahraini Listed Insurance Companies. Accounting and Finance Research, 7(3), 102-110.

Barth, M. E, Cahan, S. F., Chen, L. \& Venter, E. R. (2017). The economic consequences associated with integrated report quality: Capital market and real effects Accounting, Organizations and Society 62, 4364. http://dx.doi.org/10.1016/j.aos.2017.08.005

Bernardi, C., \& Stark, A.W. (2017). Environmental, social and governance disclosure, integrated reporting, and the accuracy of analyst forecasts. forthcoming British Accounting Review.

Bijlmakers, L. (2018). The influence of integrated reporting on firm value (Doctoral dissertation, University of Amsterdam).

Brown, J., \& Dillard, J. (2014). Integrated reporting: On the need for broadening out and opening up. Accounting, Auditing \& Accountability Journal, 27(7), 1120-1156.

Buallay, A., A. Hawaj, A.A. \& Hamdan, A. (2020). Integrated reporting and performance: a cross-country comparison of GCC Islamic and conventional banks, Journal of Islamic Marketing,Vol.ahead-ofprintNo.ahead-of-print. 
Campbell, D., Shrives, P., \& Bohmbach-Saager, H. (2001). Voluntary Disclosure of Mission Statements in Corporate Annual Reports: Signaling what and to whom? Business and Society Review, 106(1), 65-87. https://doi.org/10.1111/0045-3609.00102

Chatelain, S. P. \& Morin, S. D. (2012). The sustainable development reporting: a new organizational practice in higher education institutions? 28th EGOS Colloquium Design! Helsinki, Finland. 274.

Cheng, M., Green, W., Conradie, P., Konishi, N., \& Romi, A. (2014). The International Integrated Reporting Framework: Key Issues and Future Research Opportunities. Journal of International Financial Management \& Accounting, 25(1), 90-119.

Cosma, S., Soana, M. G., \& Venturelli, A. (2018). Does the market reward integrated report quality? African Journal of Business Management, 12(4), 78-91.

De Villiers, C., Venter, E. R., \& Hsiao, P.-C. K. (2016). Integrated reporting: background, measurement issues, approaches and an agenda for future research. Accounting \& Finance, 57(4), 937-959. https://doi.org/10.1111/acfi.12246

Eccles, R.G., Krzus, M.P., \& Watson, L.A. (2012). Integrated Reporting Requires Integrated Assurance. In J. Oringel (Eds.). Effective Auditing for Corporates: Key Developments in Practice and Procedures (BCPaperbacks.161-178).

El Deeb, M. S. (2019). The Impact of Integrated Reporting on Firm Value and Performance: Evidence from Egypt. Alexandria Journal of Accounting Research, Faculty of Commerce, Alexandria University, 3(2), 2682 - 3144.

Frias-Aceituno, J. V., Rodríguez-Ariza, L., \& Garcia-Sánchez, I. M. (2012). Explanatory Factors of Integrated Sustainability and Financial Reporting. Business Strategy and the Environment, 23(1), 56-72. https://doi.org/10.1002/bse.1765

Girella, L., Rossi, P., \& Zambon, S. (2019). Exploring the firm and country determinants of the voluntary adoption of integrated reporting. Business Strategy and the Environment.

https://doi.org/10.1002/bse.2318

Healy, P. M., \& Palepu, K. G. (2001). Information asymmetry, corporate disclosure, and the capital markets: A review of the empirical disclosure literature. Journal of Accounting and Economics, 31(1-3), 405-440. https://doi.org/10.1016/s0165-4101(01)00018-0

Hongming, X., Ahmed, B., Hussain, A., Rehman, A., Ullah, I., \& Khan, F. U. (2020). Sustainability Reporting and Firm Performance: The Demonstration of Pakistani Firms. Sage Open, 1-12. https://doi.org/10.1177/2158244020953180

Hoque, M. E. (2017). Why Company Should Adopt Integrated Reporting? International Journal of Economics and Financial Issues, 7(1) 241-248. 
Hossain, M. Hecimovic, A. \& Lema, A. (2015). Corporate Social and Environmental Responsibility Reporting Practices from an Emerging Mobile Telecommunications Market. Australian Accounting Review, 25. 389404.

Ilaboya, O. J., \& Ohiokha, I. F. (2016). Firm Age, Size and Profitability Dynamics: A Test of Learning by Doing and Structural Inertia Hypotheses. Business and Management Research, 5(1). https://doi.org/10.5430/bmr.v5n1p29

International Integrated Reporting Council (IIRC) (2021). The International <IR $>$ Framework.

Isaac, O., Abdullah, Z., Ramayah, T., Mutahar, A.M., \& Alrajawy, I. (2016). Perceived usefulness, perceived ease of use, perceived compatibility, and net benefits: an empirical study of internet usage among employees in Yemen. The 7th International Conference Postgraduate Education(ICPE7). 899-919.

Islam, M.S. (2020). Investigating the relationship between integrated reporting and firm performance in a voluntary disclosure regime: insights from Bangladesh. Asian Journal of Accounting Research, Vol. ahead-of-print No. ahead-of print. https://doi.org/10.1108/AJAR-06-2020-0039.

Iyoha, F.O., Stephen A. O. \& Oyebisi M. O. (2017). Bankers' perspectives on Integrated Reporting for value creation: evidence from Nigeria. Banks and Bank Systems, 12(2), 100-105.

https://doi.org/10.21511/bbs.12(2).2017.10

Jensen, M. C., \& Meckling, W. H. (1976). Theory of the firm: Managerial behaviour, agency costs and ownership structure. Journal of Financial Economics, 1(1), 305-360.

KIlıç, M. and Kuzey, C. (2018), "Assessing current company reports according to the IIRC integrated reporting framework", Meditari Accountancy Research, 26(2), 305- 333. https://doi.org/10.1108/MEDAR-042017-0138

Lebas, M. \& Euske, K. (2007). A conceptual and operational delineation of performance. Business Performance Measurement: Unifying Theories and Integration Practice. 125- 139. https://doi.org/10.1017/CB09780511805097.008

Lee, K.-W., \& Yeo, G. H.-H. (2015). The association between integrated reporting and firm valuation. Review of Quantitative Finance and Accounting, 47(4), 1221-1250.

Lundholm, Russell \& Winkle, Matt. (2006). Motives for disclosure and non-disclosure: A framework and review of the evidence. Accounting and Business Research, 36. 43-48.

Mukeredzi T. C. G. (2019). Impact of integrated reporting on financial performance (M.A. Dissertation, University of KwaZulu-Natal).

Nurkumalasari, I. S., Restuningdiah, N., \& Sidharta, E. A. (2019). Integrated reporting disclosure and its impact on firm value: Evidence in Asia. International Journal of Business, Economics and Law, 18(5), 99108. 
Omran, M. S. Y., Zaid, M. A. A., \& Dwekat, A. (2020). The relationship between integrated reporting and corporate environmental performance: A green trial. Corporate Social Responsibility and Environmental Management, 1-9.

Pasquini-Descomps, H. and Sahut, J.-M. (2014b), “ESG impact on market performance of firms: International evidence", 1-31.

Qiu, Y., Shaukat, A., \& Tharyan, R. (2016). Environmental and social disclosures: Link with corporate financial performance. The British Accounting Review, 48(1), 102-116.

Ross, S. A. (1977). The Determination of Financial Structure: The Incentive-Signalling Approach. The Bell Journal of Economics, 8(1), 23.

Shirley, M. M. (2016). An investigation of the integrated reporting disclosure practices of the top 40 listed South African companies, (Master minor Dissertation, University of Johannesburg).

Songini, L., Pistoni, A., Tettamanzi, P., Fratini, F. \& Minutiello, V. (2021 Integrated reporting quality and BoD characteristics: an empirical analysis: Journal of Management and Governance.

https://doi.org/10.1007/s10997-021-09568-8

Soumillion, V. (2018). The value relevance of integrated reporting in South Africa [M.Sc. Dissertation]. Universiteit Gent

Spence, M. (2002). Signaling in Retrospect and the Informational Structure of Markets. American Economic Review, 92(3), 434-459.

Suttipun, M. (2017). The effect of integrated reporting on corporate performance: Evidence from Thailand. Corporate Ownership and Control, 15(1), 133-142.

Taouab, O., \& Issor, Z. (2019). Firm Performance: Definition and Measurement Models. European Scientific Journal, ESJ, 15(1), 93.

Tlili, M., Ben Othman, H. \& Hussainey, K. (2019). Does integrated reporting enhance the value relevance of organizational capital? Evidence from the South African context. Journal of Intellectual Capital, 20 (5). 642-661.

Udofia, I. E., Fagboro, G. D \& Adeyemi, S. B. (2020). The Integrated Reporting (IR) Framework Implementation in Nigerian Listed Companies. Global Journal of Accounting, 6(1), 1-11.

Verrecchia, R. E. (1983). Discretionary disclosure. Journal of Accounting and Economics, 5, 179-194. https://doi.org/10.1016/0165-4101(83)90011-3

Vitolla, F., Raimo, N., \& Rubino, M. (2019). Intellectual Capital Disclosure and Firm Performance: An Empirical Analysis Through Integrated Reporting. 245-255. 
Zehir, C., \& Ozgul, B. (2020). Environmental orientation and firm performance: The mediation mechanism of green innovation. International Journal of Research in Business and Social Science, 9(5), 13-25. https://www.ssbfnet.com/ojs/index.php/ijr

Zhou, S., Simnett, R., \& Green, W. (2017). Does Integrated Reporting Matter to the Capital Market? Abacus, 53(1), 94-132. https://doi.org/10.1111/abac.12104 